\title{
Long-term trends in Rangeland Health of the Rough fescue Ecological Site in the Montane subregion
}
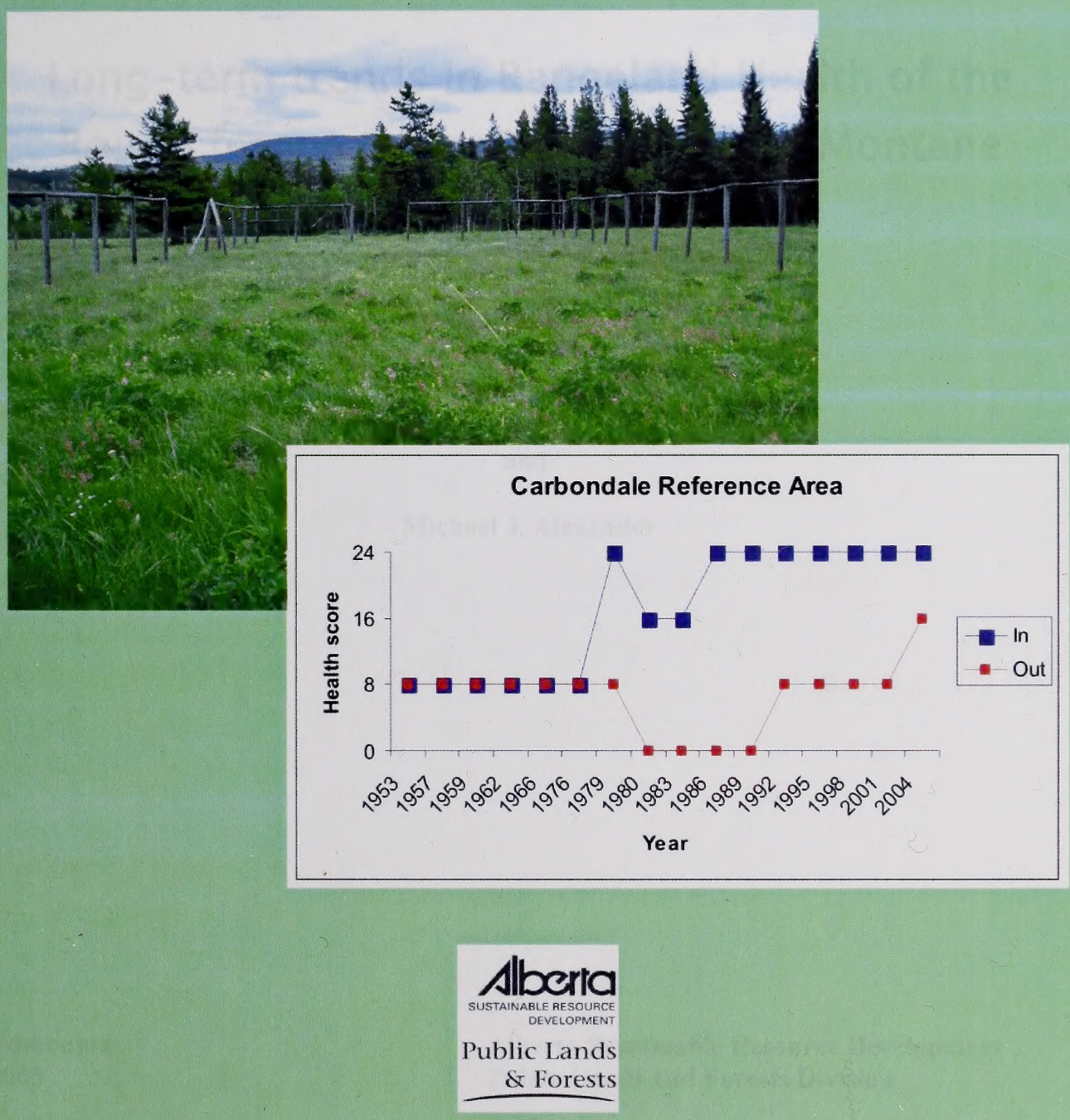


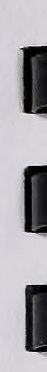




\title{
Long-term trends in Rangeland Health of the Rough fescue Ecological Site in the Montane subregion
}

\author{
Prepared by \\ Michael G. Willoughby \\ and \\ Michael J. Alexander
}


Pub No. T/069

ISBN No. 0-7785-3672-6 (Printed edition)

ISBN No. 0-7785-3673-4 (On-line edition)

For copies of this report contact:

Michael Willoughby

(780) $422-4598$

E-mail: mike.willoughby@gov.ab.ca

or

Michael Alexander

(403) 627-1131

E-mail: mike.alexander@gov.ab.ca

This report is also available on-line at:

http://www3.gov.ab.ca/srd/land/m_rm_monitoring.html 
Digitized by the Internet Archive in 2016 


\section{TABLE OF CONTENTS}

Introduction

Site description

Methods 2

Cluster analysis $\quad 2$

Ordination $\quad 2$

Analysis of rangeland health 4

$\begin{array}{ll}\text { Results } & 5\end{array}$

Historic precipitation $\quad 5$

Plant species composition $\quad 5$

Plant species diversity and richness $\quad 5$

Trends in rangeland health 5

How Integrity and Ecological status relates to rangeland health 14

$\begin{array}{ll}\text { Discussion } & 15\end{array}$

$\begin{array}{ll}\text { Plant community ecology } & 15\end{array}$

$\begin{array}{lr}\text { Rangeland health } & 16\end{array}$

Species diversity and ecological status $\quad 17$

$\begin{array}{ll}\text { Long-term trends } & 17\end{array}$

$\begin{array}{ll}\text { Literature cited } & 18\end{array}$

Appendix 1. Site characteristics of the rough fescue dominated reference areas in the Montane subregion.

\section{LIST OF TABLES}

Table 1. Foliar cover (\%) of the dominant species for each Ecological Status score of the grassland health short form in the Rough fescue ecological site of the Montane subregion.

Table 2. The relationship between Ecological Status and the other health questions for the grassland health short form in the Rough fescue ecological site of the Montane subregion.

\section{LIST OF FIGURES}



Figure 1. Example of plant community groupings and assignment of ecological status scores for each group of the Castle River Reference Area.

Figure 2. Total annual precipitation $(\mathrm{mm})$ and the 30 year average for the Beaver Mines Meteorological Station

Figure 3. The high cover of rough fescue in this figure is characteristic of an ecological status score of 24 .

Figure 4. The high diversity of native forbs and grass and the lower cover of rough fescue is characteristic of an ecological status score of 16 .

Figure 5. A low cover of rough fescue and a high cover of Kentucky bluegrass and dandelion as seen in this picture is characteristic of an ecological status score of 8 or 0 .

Figure 6. Species diversity H' for each ecological status score

Figure 7. Long term change in health of reference areas that had high ecological status when protected and show signs of recovery under grazing pressure.

Figure 8. Long term change in health of reference areas that had high ecological status when protected which show little sign of recovery under grazing.

Figure 9. Long term change in health of reference areas that had low ecological status when protected which show signs of recovery under grazing.

Figure 10. Long term health of reference areas that had low ecological status when protected which show little sign of recovery in grazed and ungrazed treatments.

Figure 11. Ecological Succession diagram, with ecological status scores and plant community codes (Willoughby et al. 2003) for the Rough fescue ecological site in the Montane subregion of Southern Alberta. 



\begin{abstract}
The Rangeland Reference Area program administered by the Public Lands and Forests Division was established by the Eastern Rockies Conservation Board to assess range condition and monitor trend on rangelands within the boundaries of the Rocky Mountain Forest Reserve (RMFR). Over fifty fenced exclosures have been established in the Forest Reserve. These exclosures include permanently marked grazed and ungrazed transects. Species composition data has been recorded on these transects since 1953 when many of the sites were established. Recently, the data of these sites has been analyzed in order to determine the successional pathways in the presence and absence of grazing. This long-term data used in conjunction with a detailed ecological classification of the range community types will help to determine the health of the rangelands in the Rocky Mountain Forest Reserve.

This report evaluates and discusses the range health and trend of the Rangeland Reference Areas that represent the rough fescue ecological site within the Montane subregion.
\end{abstract}





\section{INTRODUCTION}

In the late 1800 's livestock grazing was unregulated along the eastern slopes of the Rocky Mountains in Alberta. In an effort to protect the Saskatchewan River watershed the Rocky Mountain Forest Reserve was established in 1910. At this time grazing by domestic animals was prohibited. However, by 1913 grazing by livestock was recognized as a useful tool to reduce forage accumulation and assist in preventing a potential fire hazard. Due to inadequate management policies and funding, water quality continued to deteriorate because of fire, localized overgrazing and inadequate resource management. As a result, the Eastern Rockies Conservation Board was established to allow for collaborative federal and provincial management and monitoring of resource use in the Rocky Mountain Forest Reserve. Subsequently the Rangeland Reference Area Program was established in 1949 by the Eastern Rockies Conservation Board to assess range condition and monitor range trend on grasslands within the boundaries of the Rocky Mountain Forest Reserve (Hanson 1975). Over fifty reference areas have been established in the Reserve. Many of these sites have been monitored since 1953.

This report discusses and evaluates the trends in range health of the Rangeland Reference Areas that represent the rough fescue ecological site within the Montane subregion (Willoughby et al. 2003). There are 11 long-term reference area sites which represent the rough fescue ecological site. The oldest reference areas were established in 1953 and the newest sites were established in 1982.

\section{SITE DESCRIPTION}

The rough fescue ecological site makes up a major component of the primary rangelands in the Montane subregion of Alberta (Dept. of Environmental Protection 1994). The Montane subregion composes only $0.9 \%$ of the province and is found in an area south of Chain Lakes to the Montana border, portions of the Bow and Athabasca river valleys and isolated areas near Ya Ha Tinda and Grande Cache. The Montane is distinguished from the other subregions by the presence of Douglas fir (Pseudotsuga menziesii), limber pine (Pinus flexilis) and lodgepole pine (Pinus contorta). Elevationally the Montane occurs below the Subalpine in the mountains and above the Foothills Fescue and Foothills Parkland subregions in southern Alberta.

Yearly precipitation ranges $308 \mathrm{~mm}$ to $1279 \mathrm{~mm}$ with two precipitation peaks occurring in May-June and again in August-September (Strong 1992). Summer monthly temperatures average $11.9^{\circ} \mathrm{C}$ and are $2^{\circ} \mathrm{C}$ warmer than the Subalpine and $2^{\circ} \mathrm{C}$ colder than the Foothills Fescue subregions. The Montane has the warmest winter temperatures of any forested subregion in Alberta. This is due to the montane's association with the major east-west mountain valleys. The valleys are warm during winter as they channel warm modified Pacific air into Alberta and often escape outbreaks of cold arctic air from the north (Strong 1992).

In the Montane the modal grassland vegetation occurs on terraces and southerly facing slopes. The dominant grass species include foothills rough fescue (Festuca campestris), Parry oatgrass (Danthonia parryi), Richardson needlegrass (Stipa richardsonii), Idaho fescue (Festuca idahoensis), upland sedge species and wheatgrasses (Agropyron ssp). Moss and Campbell (1947) believed the rich flora of this subregion could be explained in terms of the continuity with the Palouse prairie through mountain passes from the Northwestern United States. Many 
species characteristic of the Palouse prairie are found in southwestern Alberta: Idaho fescue, bluebunch wheatgrass, sticky purple geranium (Geranium viscosissimum), woolly gromwell (Lithospermum ruderale), and balsamroot (Balsamorhiza sagittata). There are eleven rangeland reference areas that represent various stages of succession of the rough fescue ecological site. These sites include the Castle, Carbondale, East trout, Jim Heath, Lyndon, Livingstone, Dutch, North Rock, Waldron, Chimney Rock South and Rock Connelly reference areas. Each of these sites is representative of ungrazed and grazed rough fescue dominated community types on south and west facing slopes and terraces with morainal and glacial fluvial parent material and Black Chernozemic soils (Weerstra 1989). The site characteristics for all eleven reference areas is summarized in Appendix 1.

\section{METHODS}

Reference sites were selected from within range allotments on areas that represented primary range. Originally sites thought to be in poor range condition were selected. These sites were usually represented by open grasslands on south-facing slopes, benchlands and terraces. The reference sites were not located near salt or within $100-\mathrm{ft} .(30-\mathrm{m})$ of a fence. The preferred distance from a water source was greater than 1000-ft. (300-m) but less than 1-mi. (1.6-km).

Each reference site consisted of a fenced exclosure and a $100-\mathrm{ft}(33-\mathrm{m})$ transect inside and outside the exclosure. The outside transect was situated $25-\mathrm{ft}(8-\mathrm{m})$ or greater from the edge of the exclosure. At 3-in. (7-cm) intervals, the basal frequency of the plant species were recorded using Parker's loop (Parker 1954). In 1980, the foliar cover of the plant species was also recorded (at 6-ft. (2.0 m) intervals) using a 20x50 cm Daubenmire frame. Presently, the transects are being recorded every three years. All the basal frequency data prior to 1980 was converted to canopy cover using regression analysis for each site (Willoughby 1997).

A combination of of both ordination (DECORANA) (Gauch 1982) and cluster analysis (SAS) were used to group the inside and outside transects of different years within each reference site. These techniques combined the sites based on the similarity of species composition.

\section{Cluster analysis}

Cluster analysis or classification is the assignment of samples to classes or groups based on the similarity of species. A polythetic agglomerative approach was used to group the samples. This technique assigns each sample to a cluster which has a single measure. It then agglomerates these clusters into a hierarchy of larger and larger clusters until finally a single cluster contains all the samples (Gauch 1982). Cluster analysis was performed in SAS and Euclidean distance was used as the Cluster Distance Measure and Ward's method was used in the Group Linkage Method. The groupings generated in cluster analysis were overlain on the site ordination to determine final groupings.

\section{Ordination}

Ordination was used to find relationships among species, communities and environmental 

variables. The ordination technique used in the analysis of the monitoring data was DECORANA (Detrended Correspondence Analysis). Groupings were determined by looking for a divergence of the ungrazed and grazed transects for each year into groups with similar species composition which were called community types (Figure 1). Once final groupings for each site were completed mean species cover were summarized for each year within a group to form a species list. These species lists were assigned to a particular community type within a reference area.

\section{Castle}

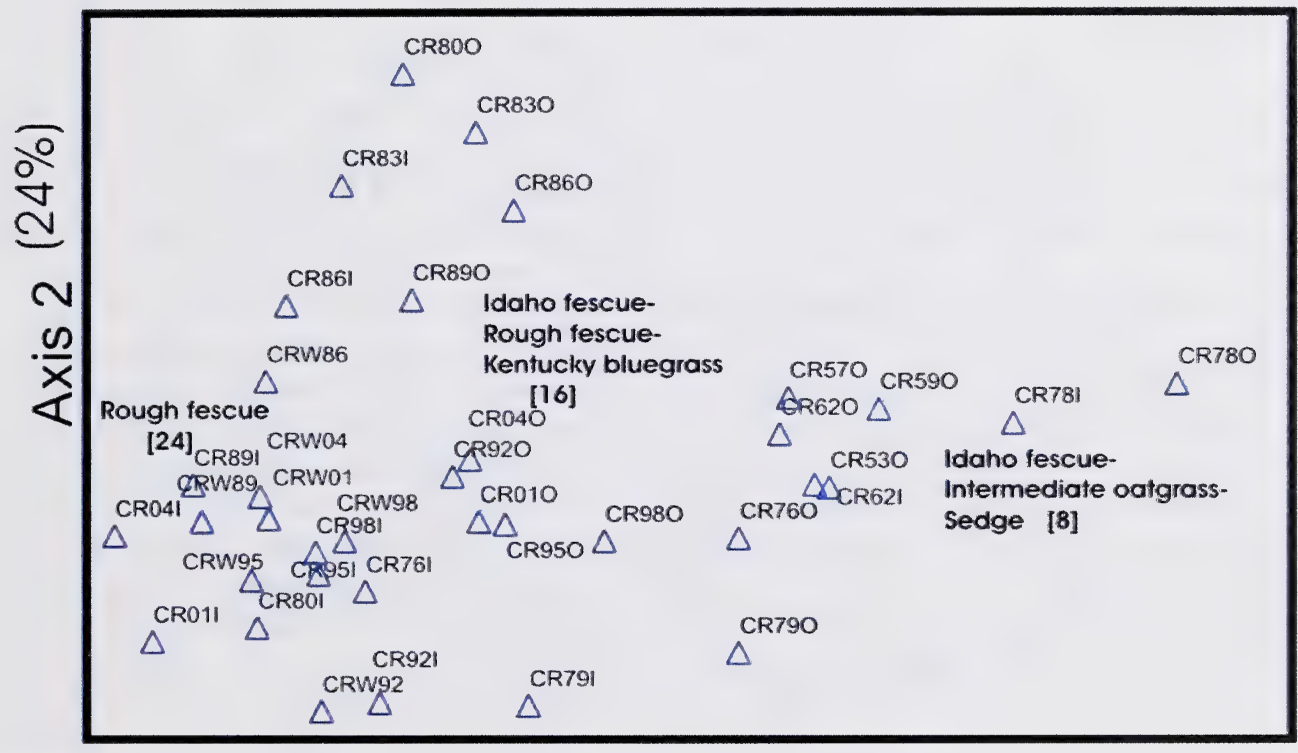

\section{Axis $1(36 \%)$}

Figure 1. Example of plant community groupings and assignment of ecological status scores for each group of the Castle River Reference Area. The year " 89 " represents year of recording, "I" refers to Inside transect, "O" refers to Outside transect, "W" refers to wildlife exclosure transect. Note the divergence of the inside and outside transects from the original Idaho fescue (1953-1979 In and Out) dominated community into different plant communities represented by rough fescue (1979-2004) on the inside transects and the Idaho fescue-Rough fescue-Kentucky bluegrass (1980-2004) plant community on the outside transects. 



\section{Analysis of rangeland health}

"Rangeland Health" is a term used to describe the ability of rangelands to perform certain key ecological functions. The term health conveys the meaning that all parts of the rangeland system are present and working properly (Adams et al. 2003). The functions of healthy range include: net primary production, maintenance of soil/site stability, capture and beneficial release of water, nutrient and energy cycling and functional diversity of plant species.

The Alberta Rangeland Health Protocol was developed as a means for assessing the health of Alberta's rangelands (Alberta Rangeland Health Task Group 1999). Rangeland health assessments are utilized to make a rapid determination of the ecological status of rangeland. We use range health terminology (healthy, healthy with problems, or unhealthy), to rank the ability of rangeland to perform certain ecological functions. There are five questions within the health assessment that rate the ecological functions of a site. These functions include: net primary production (Structure), maintenance of soil/site stability (Erosion), capture and beneficial release of water (Litter), nutrient and energy cycling (Litter) and plant species functional diversity (Ecological integrity and status and Noxious weeds). For a detailed description on how to assess rangeland health for various plant communities please refer to "Rangeland Health Assessment for Grassland, Forest and Tame Pasture" (Adams et al. 2003).

Unfortunately, there was not enough historical data from the reference areas to do a detailed rangeland health assessment for each year within a site. Therefore only the ecological integrity and status score of the rangeland health form was used to rate the health of each year within a reference site. The community type within a reference area was assigned an integrity and ecological health status score of $24,16,8$ or 0 to each year within the group (Adams et al. 2003). An Integrity and ecological status score of [24] indicates a community type that closely resembles the reference plant community for the site and alteration of the plant community due to grazing or other disturbances is minimal. A status score of [16], indicates that compared to the reference plant community, the plant community shows minor alteration, due to grazing or other disturbances. A status score of [8] indicates a community that compared to the reference plant community shows moderate alteration, due to grazing or other disturbances. A community showing significant alterations, due to grazing or other disturbances, compared to the reference plant community was assigned a score of [0] (Figure 1).

The historic integrity and ecological status scores determined for the reference area plant communities were then compared to recent rangeland health assessments where all the rangeland health ecological functions were assessed. The scores for each of the other ecological functions assessed by the remaining four rangeland health questions were then summarized within each integrity and ecological status score $24,16,8$ and 0 . For the rangeland reference area sites, species foliar cover, species richness and species diversity index $\left(H^{\prime}\right)($ Peet 1974) were also summarized for each integrity and ecological status score analyzed using analysis of variance on ranks using NPAR1WAY in SAS, with years within a group as replicates . 



\section{Historic precipitation}

\section{RESULTS}

Total yearly precipitation and the 30 year average for Beaver mines Meterological station, in the middle of the study area is outlined in Figure 2. The 1940's, 50's and 60's had precipitation levels near normal. Only 3-4 years in each decade had precipitation levels below the 30 year average of $654 \mathrm{~mm}$. In contrast the 1970's had 7 years with below average precipitation and the 1980's was the driest decade on record. Eight of the ten years had below normal precipitation and the average for the whole decade was $568 \mathrm{~mm}$. In the 1990's precipitation has been well above normal averaging over $680 \mathrm{~mm}$ with only 3 years in the decade with below average precipitation. In contrast the 2000 decade has had below average precipitation for 3 of the last 4 years.

\section{Plant species composition}

The species composition for each ecological status score for the eleven reference areas that represent the rough fescue ecological site in the Montane subregion is summarized in Table 1. In general a community type that was ungrazed and dominated by rough fescue, with subdominants of parry oatgrass, sedge and Idaho fescue was assigned a status score of [24], a parry oatgrass or Idaho fescue dominated community with a significant component of rough fescue was assigned a status score of [16]. On moist sites Kentucky bluegrass becomes a significant part of the plant community when the ecological status score is [8], but there is still a strong component of native species like parry oatgrass, Idaho fescue and sedge species in this community type. In contrast on drier sites and in years of drought sedge will often replace Kentucky bluegrass as dominant or co-dominant part of the plant community when the ecological status score is [8]. A community dominated by Kentucky bluegrass, yarrow, Canada thistle, dandelion and timothy scored a [0]. On drier sites in years of drought when the dominant plant species was little clubmoss the ecological status score was also often [0].

Examples of the 24,16, 8 and 0 ecological status scores are outlined in Figures 3, 4 and 5.

\section{Plant species diversity and richness}

When the species diversity ( $\left.\mathrm{H}^{\prime}\right)$ of these plant communities is plotted against the ecological status score (Figure 6) maximum species diversity occurred with an ecological status score of 8. Species diversity tended to be slightly lower under ecological status scores of 16 and 24. The lowest species diversity was found under an ecological status score of 0 (Figure 6). Plant species richness (number of species/plot) tended to follow the same trends as species diversity. The lowest species richness was found with a ecological status score of [0] (Table 1).

\section{Trends in Rangeland Health}

Long-term trends in rangeland health ecological status of the ten reference area sites that had grazed and ungrazed transects are outlined in Figures 7, 8,9 and 10. Trends in health tend to be different depending on the initial ecological status when the site was protected, on climate and 
grazing history. Sites which had high ecological status [16] when they were first protected generally improved on average within 15 years of being protected from grazing (Figures 7 and 8). In contrast sites which had lower ecological status when they were first protected [8] (Figure 9) generally took on average 25 years to recover to full ecological status when protected from grazing. There were two sites where the ecological status was so low when they were protected that they have shown little recovery in 20 to 40 years of no grazing pressure (Figure 10). These sites tended to be dominated by Kentucky bluegrass and dandelion when they were first protected and there has been a significant invasion of smooth brome at the Rock Connelly site (Figure 10). Slightly drier sites (Carbondale, Dutch Creek, South Chimney Rock) were affected by drought conditions during the 1980's (Figures 7 and 9). The 1980's was one of the driest decades on record with 8 of the 10 years with below average precipitation(Figure 2). The ecological status of both the grazed transect and ungrazed transect at the Carbondale and Dutch Creek sites were lower in the early to mid 1980's and the ecological status of the Chimney Rock South site was lower on the grazed transect in the mid 1980's and again in 2001.

In general the ecological status of the grazed transects were all lower than the ungrazed inside transects (Figures 8 and 9) and the grazed transects tended to more susceptible to drought conditions in the 1980's and early 2000's (Figure 7). However, if the ecological status was too low when they were first protected from grazing there was no improvement in ecological status (Figure 10).

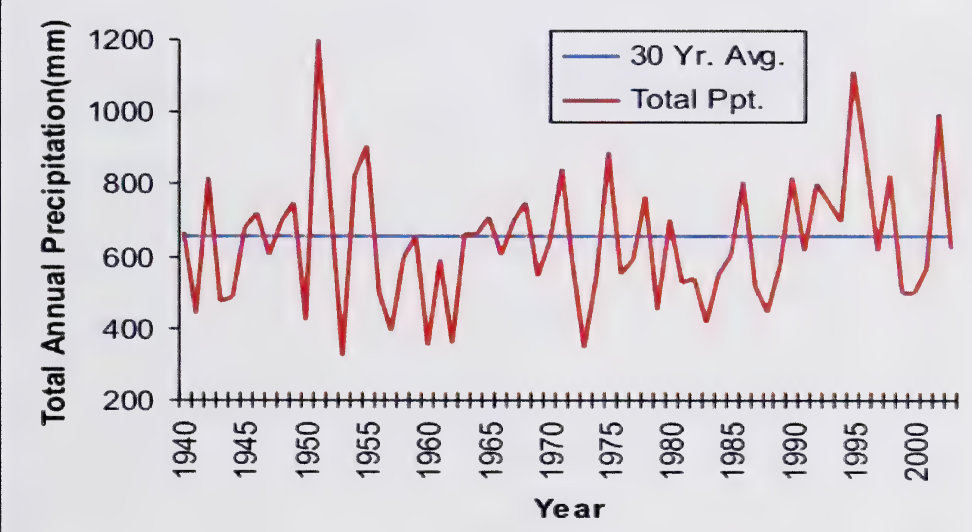

Figure 2. Total annual precipitation $(\mathrm{mm})$ and the 30 year average for the Beaver Mines Meteorological Station (Environment Canada http://www.climate.weatheroffice.ec.gc.ca/advanceSearch/) 

Table 1. Foliar cover (\%) of the dominant species for each Ecological Status score of the grassland health short form in the Rough fescue ecological site of the Montane subregion.

Health score (Ecological Status)

Species

\section{Shrubs}

PRICKLY ROSE

(Rosa arkansana)

SHRUBBY CINQUEFOIL

(Potentilla fruticosa)

\section{Forbs}

STICKY PURPLE GERANIUM

(Geranium viscosissimum)

OLD MAN'S WHISKERS

(Geum triflorum)

YARROW

(Achillea millefolium)

CANADA THISTLE

(Cirsium arvensis)

LITTLE CLUBMOSS

(Selaginella densa)

YELLOW BEARDTONGUE

(Penstemon procerus)

DANDELION

(Taraxacum offincinale)

\section{Grasses}

IDAHO FESCUE

(Festuca idahoensis)

BLUNT SEDGE

(Carex obtusata)

KENTUCKY BLUEGRASS

(Poa pratensis)

RICHARDSON NEEDLEGRASS

(Stipa richardsonii)

ROUGH FESCUE

(Festuca scabrella)

INTERMEDIATE OATGRASS

(Danthonia californica)

PARRY OATGRASS

(Danthonia parryi)

TIMOTHY

(Phleum pratense)

JUNEGRASS

(Koeleria macrantha)

SPECIES DIVERSITY ( $\mathrm{H}^{\prime}$ )

SPECIES RICHNESS

TOTAL NUMBER OF PLOTS

\begin{tabular}{llll}
\hline 24 & 16 & 8 & 0
\end{tabular}

$2 \mathrm{~A}$

$2 \mathrm{~A}$

$1 \mathrm{~A}$

$5 \mathrm{~A}$

$3 \mathrm{~A}$

OB

TA

$5 \mathrm{~A}$

TC

4B

$5 \mathrm{~A}$

$3 \mathrm{C}$

$4 \mathrm{~A}$

$23 \mathrm{~A}$

$1 \mathrm{~A}$

$6 \mathrm{~B}$

TA

$1 \mathrm{~A}$

$2.2 \mathrm{~A}$

$16.5 \mathrm{~A}$

106
2A

$1 \mathrm{~A}$

TA

$5 \mathrm{~A}$

$2 \mathrm{~A}$

$\mathrm{TB}$

$1 \mathrm{~A}$

1B

$1 \mathrm{C}$

4B

$5 \mathrm{~A}$

4C

2B

7B

$1 \mathrm{~A}$

9A

$1 \mathrm{~A}$

$1 \mathrm{~A}$

2.3A

$17.3 \mathrm{~A}$

80
$1 \mathrm{~A}$

2A

OA

2B

$4 \mathrm{~A}$

$1 \mathrm{~A}$

2A

1B

$6 \mathrm{~A}$

3B

TB

1B

$35 \mathrm{~A}$

TC

3c

TA

TC

$2 \mathrm{~A}$

TA

$1.8 \mathrm{~B}$

$17.3 \mathrm{~A}$

65

*Means with the same letter indicate no significant difference at the $p=0.05$ level according to a Kruskal-Wallis test. 



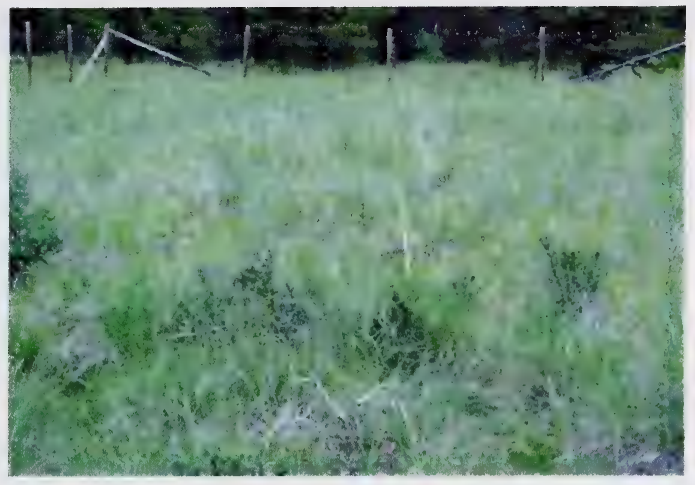

Figure 3. The high cover of rough fescue in this figure is characteristic of an ecological status score of 24 .

Figure 4. The high diversity of native forbs and grass and the lower cover of rough fescue is characteristic of an ecological status score of 16 .
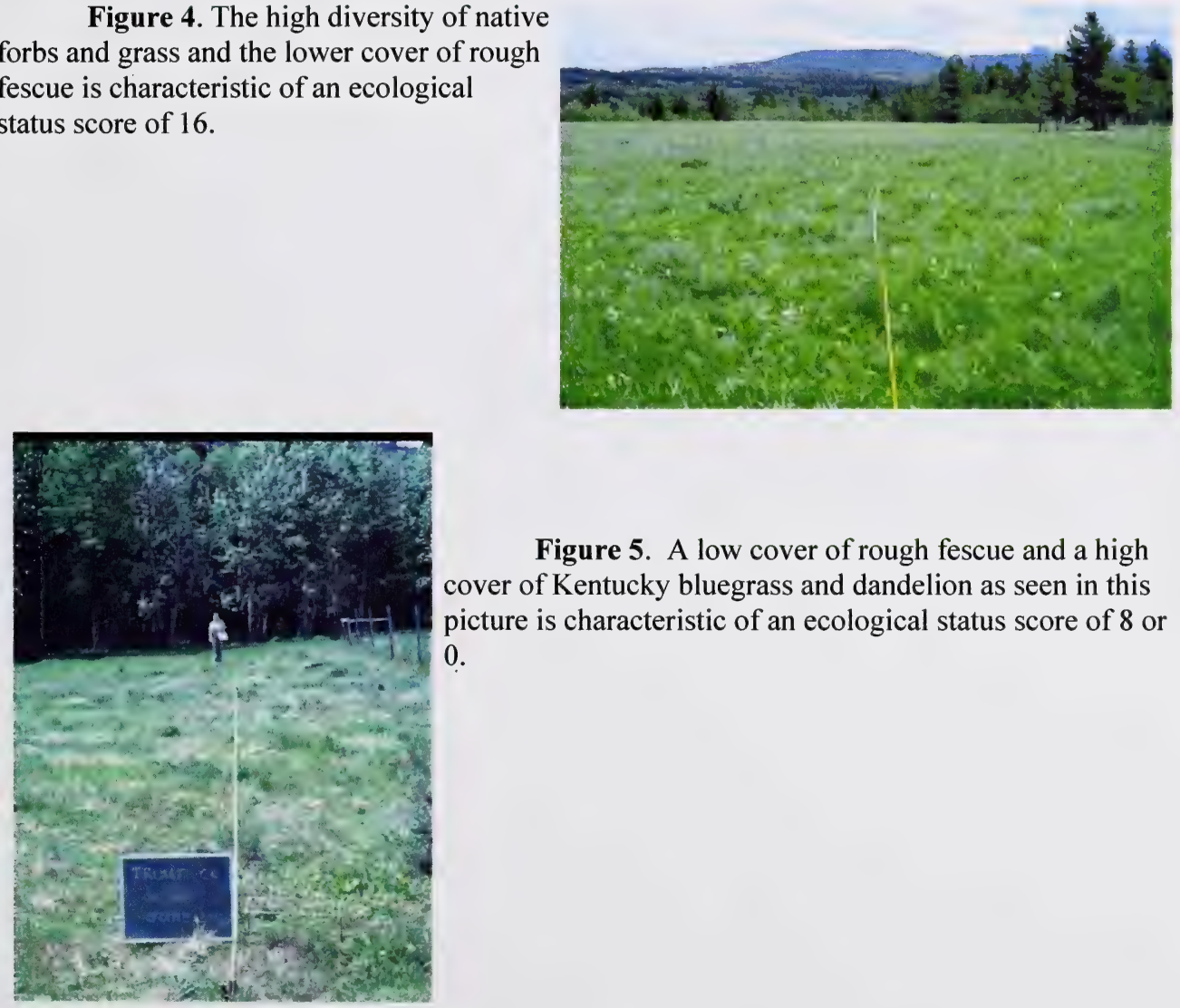

Figure 5. A low cover of rough fescue and a high cover of Kentucky bluegrass and dandelion as seen in this picture is characteristic of an ecological status score of 8 or 0 . 



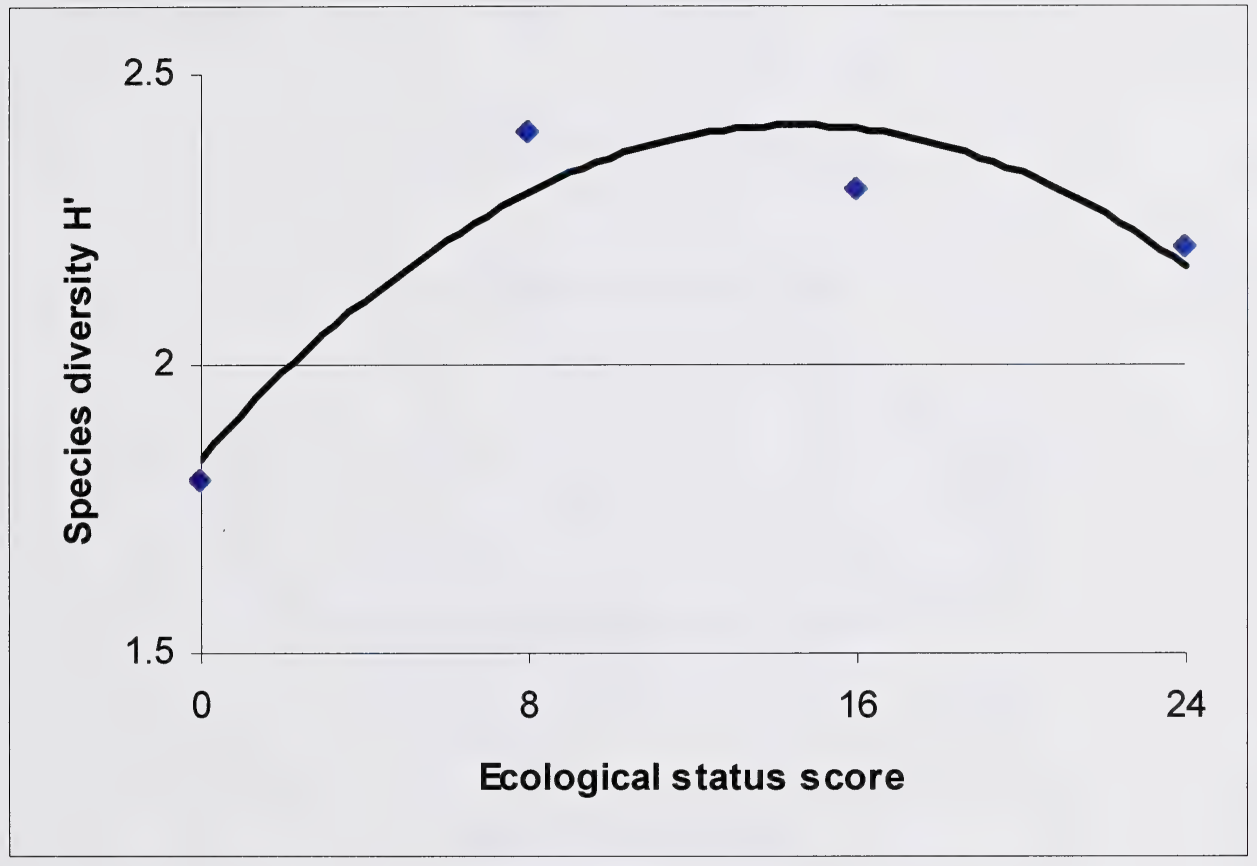

Figure 6. Species diversity H' for each ecological status score. 

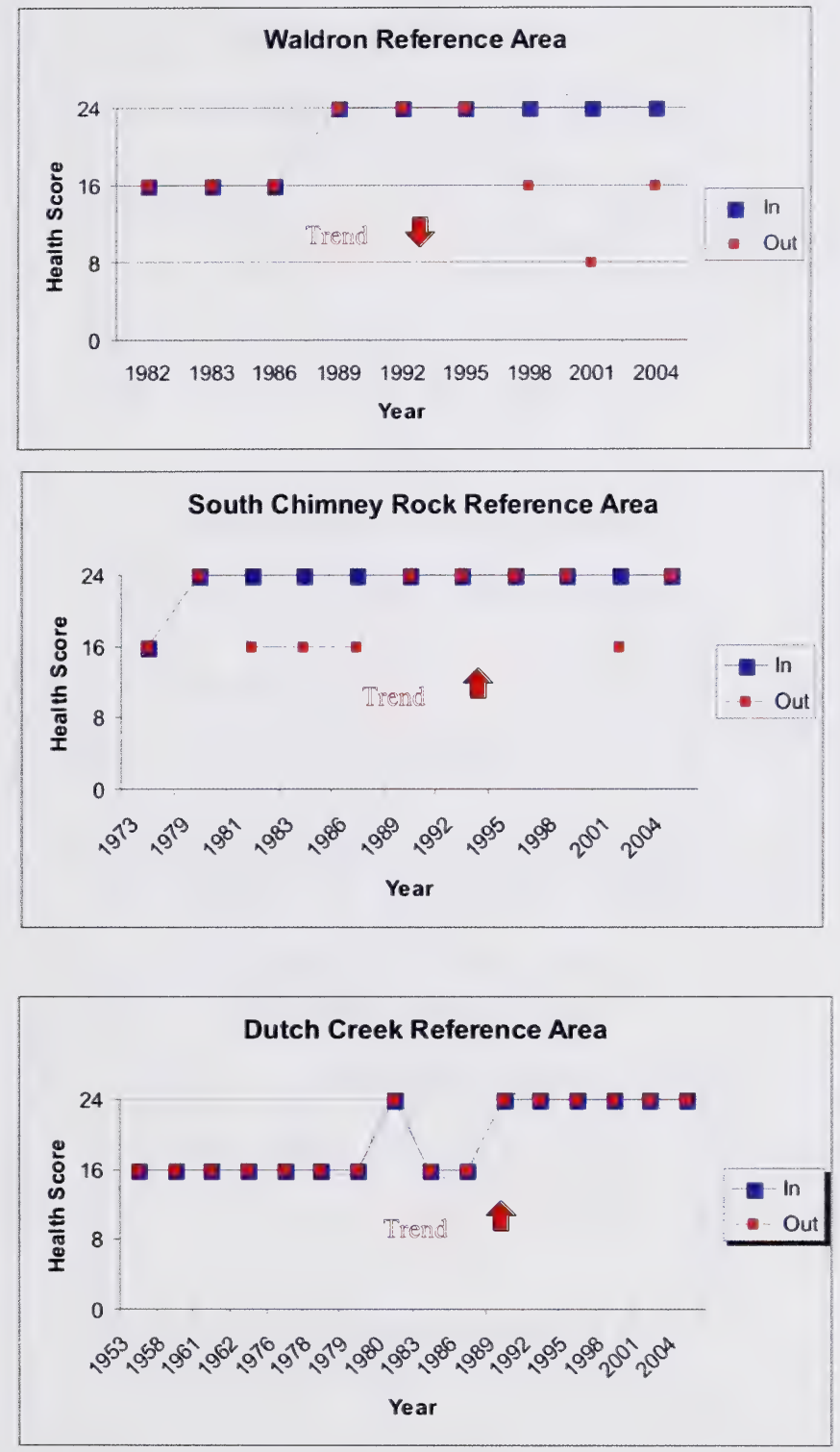

Figure 7. Long term change in health of reference areas that had high ecological status when protected and show signs of recovery under grazing pressure. 


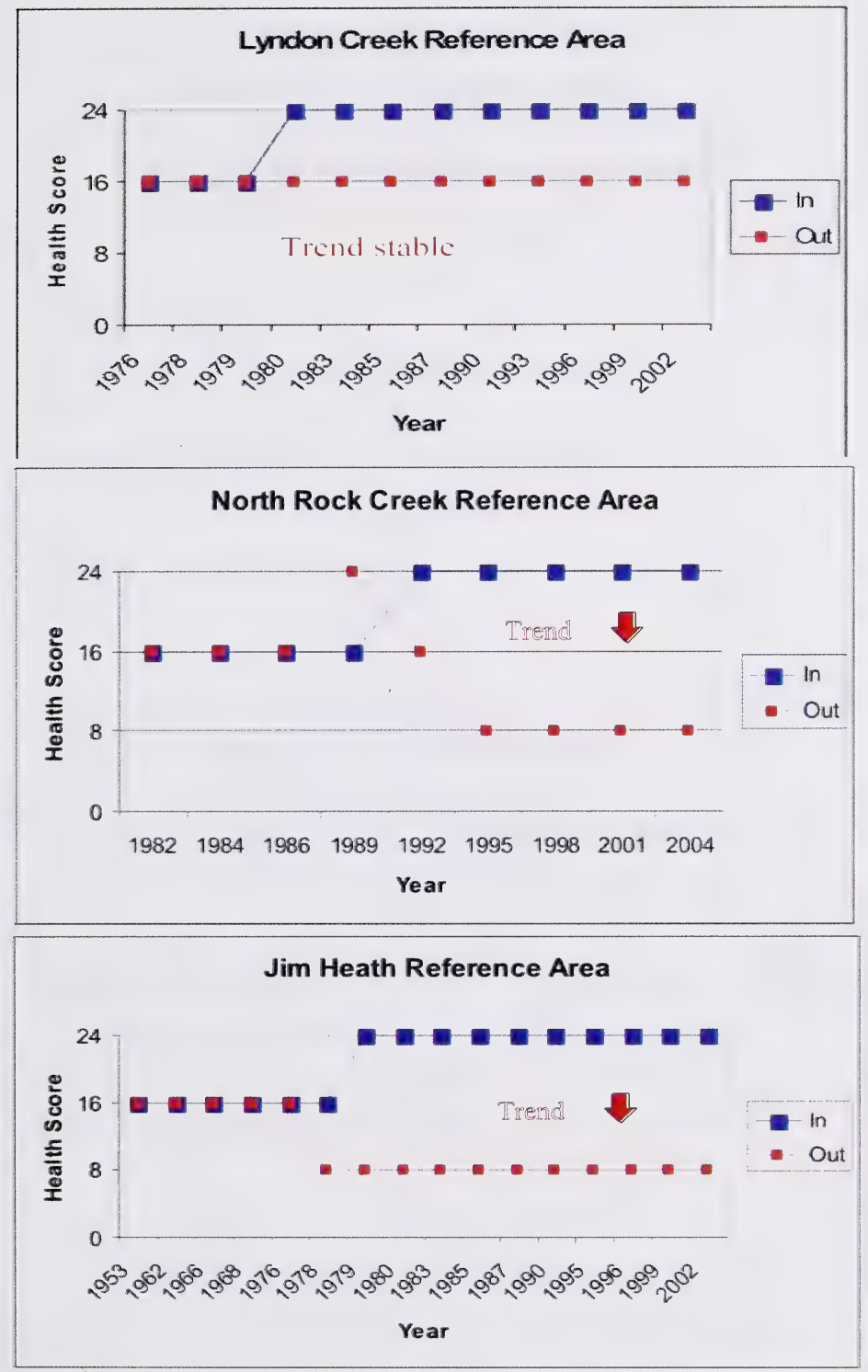

Figure 8. Long term change in health of reference areas that had high ecological status when protected which show little sign of recovery under grazing. 


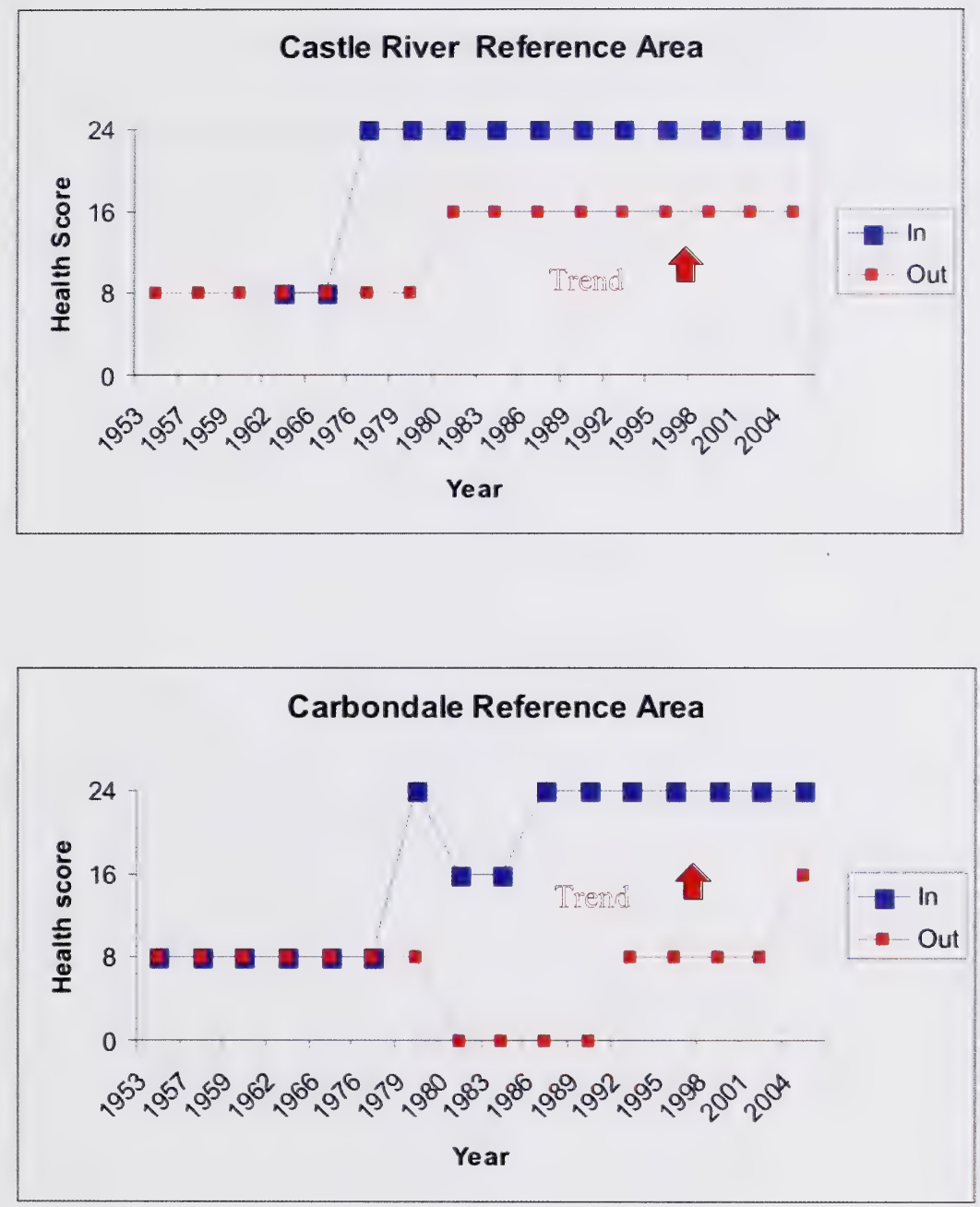

Figure 9. Long term change in health of reference areas that had low ecological status when protected which show signs of recovery under grazing. 


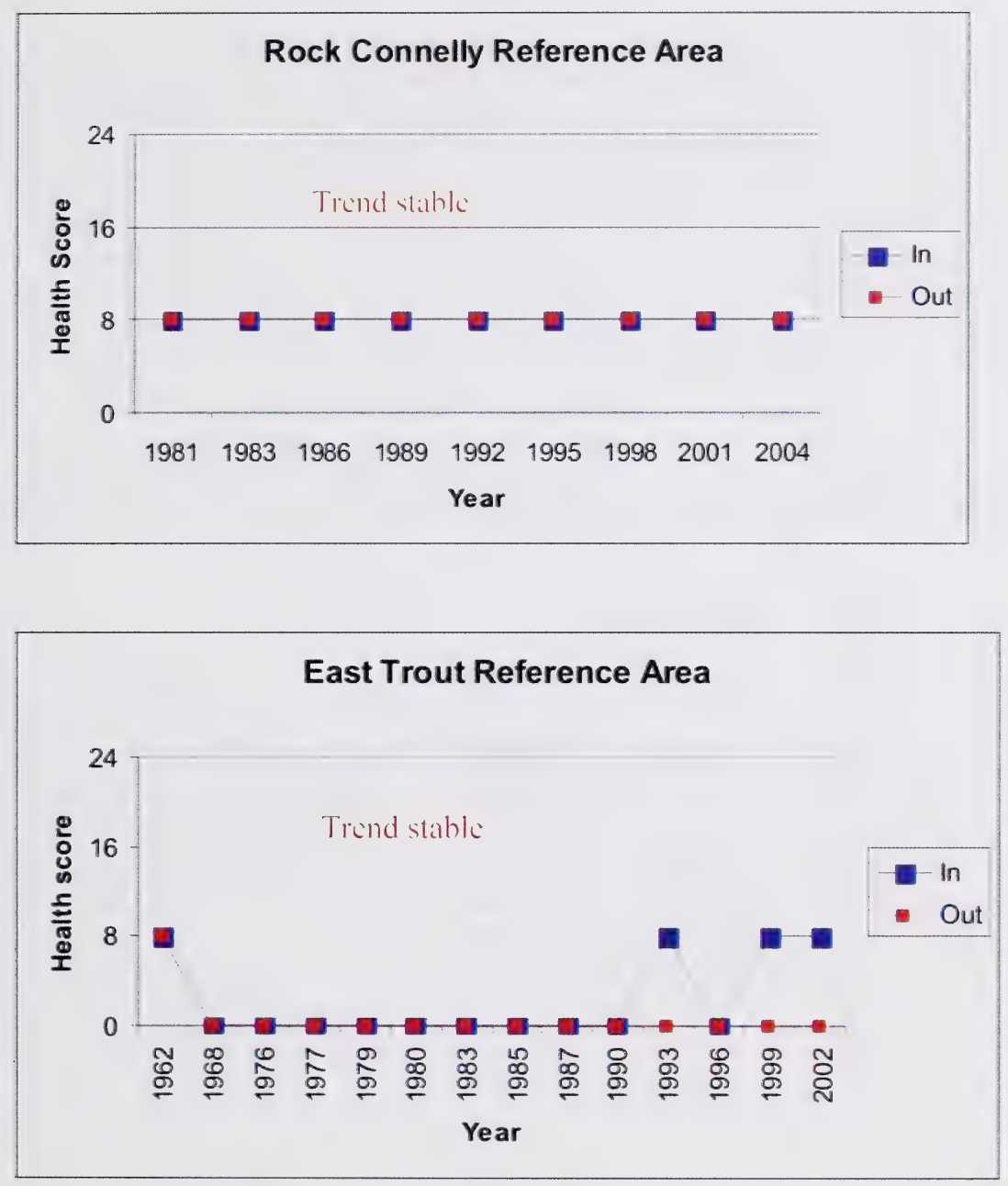

Figure 10. Long term health of reference areas that had low ecological status when protected which show little sign of recovery in grazed and ungrazed treatments. 



\section{How Integrity and Ecological status scores relate to rangeland health}

Ecological status scores of [24] and [16] generally had good plant community structure, they had high litter levels, they were dominated by native species, they exhibited little bare ground and had very few weeds present in the community (Figures 3 and 4, Table 2). The rangeland health score averaged $98 \%$ and $77 \%$ for the ecological status scores of [24] and [16], respectively (Table 2 ). These scores are within the Healthy category for rangeland health. In contrast an ecological status score of [8] or [0], had lower plant community structure, they tended to be dominated by non-native species like Kentucky bluegrass, they had lower litter levels, they exhibited some bare ground and had higher cover of noxious weeds (Figure 5, Table 2 ). The rangeland health scores averaged $61 \%$ for an ecological status score of [8] and less than $50 \%$ for an ecological status score of [0] (Table 2). These scores would be rated as healthy with problems and unhealthy, respectively (Adams et al. 2003).

Table 2. The relationship between Ecological Status and the other health questions for the grassland health short form in the Rough fescue ecological site of the Montane subregion.

Ecological Status Score (mean)

Question (maximum)

\begin{tabular}{llll}
\hline 24 & 16 & 8 & 0
\end{tabular}

1. Integrity and Ecological Status (24)

24(24)

$4-6(5.3)$

3. Hydrologic Function (Litter)(15)

4. Site Stability (Erosion)(9)

5. Noxious weeds (6)

Total score (100)

Number of plots
8-15(14.4)

9(9)

4-6(5.8)

88-100(98)

12

$\begin{array}{lll}16(16) & 8(8) & 0(0) \\ 4-6(5.2) & 2-4(3.8) & 0-2(2) \\ 8-15(10.8) & 8-15(9.6) & 0-8(7) \\ 8-9(8.6) & 6-9(8.4) & 3-9(6) \\ 4-6(5.8) & 4-6(3.3) & 0-4(2) \\ \mathbf{7 1 - 8 5 ( 7 7 )} & \mathbf{5 0 - 7 0 ( 6 1 )} & <\mathbf{5 0} \\ 5 & 8 & 1\end{array}$





\section{Plant community ecology}

\section{DISCUSSION}

The successional sequences for the Rough fescue ecological site are outlined in Figure 11. Protection from grazing on a Idaho fescue-Parry oatgrass-Sedge dominated community type will allow rough fescue to increase, to form the rough fescue dominated community type. Moss and Campbell (1947) and Willoughby et al. (2003) found that rough fescue grows almost to the exclusion of other plants in the absence of disturbance and that rough fescue declined and Parry oatgrass and Idaho fescue increased with increased grazing pressure. On moist sites with moist climatic conditions continued heavy grazing pressure of the Idaho fescue-Parry oatgrass-Sedge dominated community type will eventually lead to a community type dominated by Kentucky bluegrass, timothy, smooth brome and dandelion. Moss and Campbell (1947), Looman (1969), Willms et al. (1985) and Willoughby and Alexander (2000), all found that long-term heavy grazing pressure eventually leads to a decline in rough fescue and an increase in Kentucky bluegrass. The old climax range condition model suggests that vegetation will be directional, predictable and revert back to the original rough fescue dominated pre-disturbance plant community in time. This concept appears to be applicable to the Rough fescue ecological site up to the point in time before Kentucky bluegrass dominates the community. Once Kentucky bluegrass invades the community the traditional range condition model does not apply and the vegetation dynamics closely follow the state and threshold model (Laycock 1991). This model implys that the grassland species composition moves to the point of stabilization with plant species that have invaded rather than succeed back to the original vegetation. It appears once Kentucky bluegrass becomes established it continues to remain co-dominant with rough fescue even in the absence of disturbance. This successional sequence was demonstrated at the East Trout and Rock Connelly reference sites (Figure 10).

However, on drier sites with dry climatic conditions succession in the presence of grazing will often lead to a community type dominated by sedge and little clubmoss. This successional sequence was demonstrated on the outside transect at the Carbondale reference area during the 1980 's the driest decade on record (Willoughby 1997). However, this same outside transect quickly became dominated by Kentucky bluegrass as moisture increased during the 1990's.

Kentucky bluegrass cover also seems to increase in the absence of disturbance during years with increased moisture. At the Castle reference area the moist conditions during the 1990 's caused the inside ungrazed transects to succeed to a Rough fescue-Kentucky bluegrass dominated community type (Willoughby 1997). However, during the dry years of 2000, 2001 and 2002, Kentucky bluegrass cover has declined to only 4 and $5 \%$ foliar cover and the inside transects are again dominated by rough fescue in 2004.

The lack of fire also appears to allow trees to encroach onto the rough fescue dominated ecological site to form Douglas fir, lodgepole pine and aspen dominated community types (Figure 11). However, the time frame for complete tree invasion is still unclear. The Livingstone reference area which has not been grazed or burned for over 40 years is exhibiting signs of lodgepole pine invasion (Willoughby and Alexander 2000). 


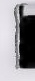

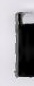

I

I

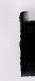

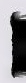

I

I

I

I

I

I

1

1

1

I

I

1 


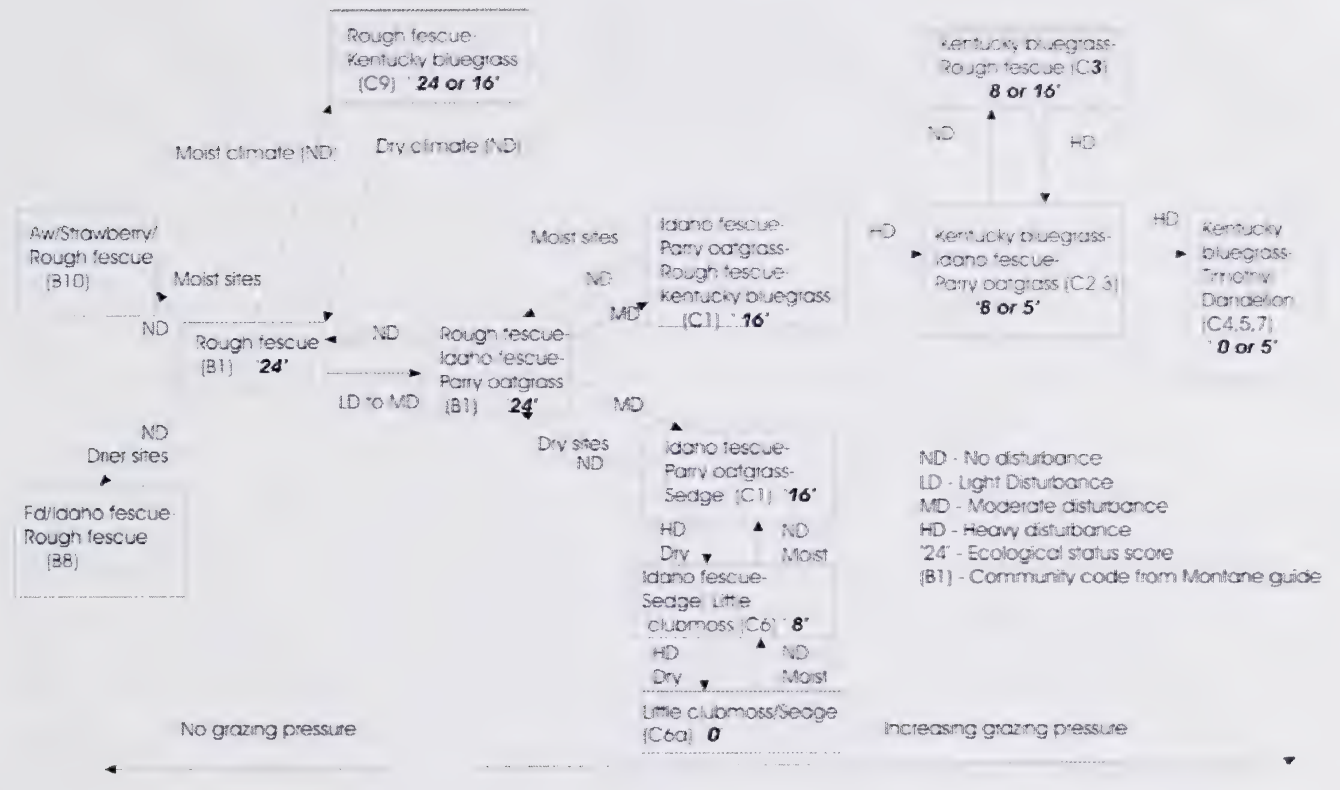

Figure 11. Ecological Succession diagram, with ecological status scores and plant community codes (Willoughby et al. 2003) for the Rough fescue ecological site in the Montane subregion of Southern Alberta.

\section{Rangeland health}

New rangeland health protocols have been developed for Alberta rangelands which include measures of plant community integrity and ecological status, site stability, hydrologic function, nutrient cycling and energy flow, plant community structure and noxious weeds (Adams et al. 2003). Ratings are based on a percentage of possible scores for each category. The total possible score is 60 and rangelands are rated as Healthy $(>75 \%)$, Healthy with problems $(50-75 \%)$ and Unhealthy $(<50 \%)$. These ratings help to determine if a particular ecological site is functioning properly. In the Montane subregion of Alberta, rangeland health ratings that have been done on sites that are representative of the rough fescue ecological site that scored healthy generally had ecological status scores of [24] or [16] and were generally represented by a plant community that was dominated by rough fescue, parry oatgrass, Idaho fescue or sedge species. These sites often had high species diversity. In contrast Unhealthy or Healthy with problems rangeland health ratings generally had low ecological status scores of [8] or [0] and were represented by plant communities dominated by Kentucky bluegrass, yarrow, Canada thistle, dandelion and timothy. The unhealthy sites often had the lowest species 

diversity. It would appear that using ecological status scores from the present rangeland health ratings to report trends in range condition and health from long-term monitoring plots does provide meaningful results. Clearly, the changes in ecological status over-time in the presence and absence of disturbance coincides with changes to species composition and rangeland health for each reference area.

\section{Species diversity and Ecological status}

One of the key factors affecting plant species diversity on rangelands is environmental stress. Grime (1973) concluded that species diversity could be plotted as a bell-shaped curve along gradients of environmental stress. Under low environmental stress (grazing, drought, pollution), some species dominate the site by shading lower growing species. As environmental stress increases, the species adapted to low environmental stress lose their competitive advantage and species more resistant to environmental stress are allowed to increase in abundance. With moderate levels of stress, both species resistant to stress and the species susceptible to stress are able to survive and reproduce resulting in maximum species diversity. Willoughby (1995), found with no grazing stress, rough fescue out competes and suppresses other native plant species. When grazing stress increases, the dominant species (because it is the most abundant, available, and preferred forage) loses its competitive advantage to the more grazing resistant and less desirable plant species. Consequently, there is a decline in rough fescue and an increase in parry oat grass, sedge, Idaho fescue, and various forb species which results in an overall increase in species diversity. As grazing pressure continues to increase, native plant species decline and are eventually removed from the site. The native species are replaced by non-native invaders such as Kentucky bluegrass, timothy, and dandelion which are highly resistant to grazing, dominate the site, resulting in lower species diversity.

When the species diversity of the various ecological status scores is plotted along Grime's curve, maximum species diversity occurs with an ecological status score of [8] (Figure 6). This implies that this plant community is under a moderate level of stress. In contrast an ecological status score of [0] which represents Kentucky bluegrass and timothy plant communities that have experienced heavy grazing for 20-30 years has the lowest species number and diversity (Table 1).

However, managing for maximum species diversity, which requires a moderate level of stress and an ecological status of [8], clearly does not promote a healthy grassland. Once species diversity is maximized, the stress resistant plant species easily outcompete the susceptible plant species. The competitive advantage is shifted to the stress resistant species and the long-term health of the rangeland is affected (Figure 10).

\section{Long term trends}

When examining long-term trends in health of these reference areas over $70 \%$ of the sites exhibit stable or improving trends in rangeland health (Figures 7,8,9 and 10). Two of the three sites that did exhibit downward trends in health (North Rock, Jim Heath) have livestock distribution problems associated with the exclosure site. At both sites livestock are attracted to the area around the exclosure because of access to water and exposure to wind for insect relief. 

In both instances livestock use on the remaining area of the disposition has been good and rangeland health ratings are healthy or healthy with problems. However, at the Waldron site (Figure 7) the decline in rangeland health ratings on the grazed transect in the late 1990's and early 2000 's does reflect a change in management of the whole disposition. The manager of the disposition was experimenting with a new grazing system in the early 2000 's and the area around the exclosure was grazed heavily during very dry years in 2000 and 2001.

Clearly, these reference areas have only limited value in reporting the health and trend of all rough fescue dominated rangelands in the landscape of the Montane subregion. These sites only represent 11 points in the landscape. In order to report the trend and status of all rough fescue grasslands in the Montane repeated rangeland health ratings on all dispositions over a period of time will have to be recorded.

\section{LITERATURE CITED}

Adams, B.W., G. Ehlert, C. Stone, D. Lawrence, M. Alexander, M. Willoughby, C. Hincz, D. Moisey, and A.Bogen. 2003. Rangeland Health Assessment for Grassland, Forest and Tame Pasture. Alberta Sustainable Resource Development. Public Lands Division. Edmonton. AB. Pub. No. T/044. 104pp.

Alberta Rangeland Health Task Group. 1999. Terms of Reference. Alberta Agriculture Food and Rural Development and Alberta Environment. Edmonton. AB. 12pp.

Dept. of Environmental Protection. 1994. Natural Regions of Alberta. Dept. of Environmental Protection. Pub. no. I/531. 18pp.

Environment Canada Weather for Beaver Mines Meteorological Station http://www.climate.weatheroffice.ec.gc.ca/advanceSearch/)

Gauch, H.G. 1982. Multivariate analysis in community ecology. Cambridge University Press, Cambridge, 298pp.

Grime, J.D. 1973. Control of species diversity in herbaceous vegetation. J. Environ. Manage. 1:151-167.

Laycock, W.A. 1991. Stable states and thresholds of range condition on North American rangelands-a viewpoint. J. Range Manage. 45:427-433.

Looman, J. 1969. The fescue grasslands of Western Canada. Vegetatio, 19:28-145.

Moss, E.H. and J.A. Campbell. 1947. The fescue grassland of Alberta. Can. J. Res. 25:209-227.

Parker, K.W. 1954. A method for measuring trend in range condition on national forest ranges.

U.S. Forest Service, Washington, D.C. 26pp. 
Peet, R.K. 1974. Species diversity. Ann. Rev. Ecol. and System. 5:245-289.

Strong, W.L. 1992. Ecoregion and ecodistricts of Alberta. Vol. 1. Alberta Forestry, Lands and Wildlife, Land Information Services Division, Resource Information Branch, Edmonton, Alberta. T/244. 77pp.

Weerstra, B.G. 1989. Rangeland reference areas of the Alberta Forest Service. Range Management Section, Alberta Forest Service, Edmonton, Alta. 95pp.

Willms, W.D., S. Smoliak and J.F. Dormaar. 1985. Effects of stocking rate on a rough fescue grassland vegetation. J. Range Manage. 38:220-225.

Willoughby, M.G. 1995. Species diversity and how it is affected by livestock grazing on Alberta's Eastern Slopes. Proc. 5th Int'l Rangeland Congress. Salt Lake City. Utah. pp 610-611.

Willoughby, M.G. 1997a. Rangeland Reference Areas, Castle River, Range condition and trend from 1953-1995. Dept. of Environmental Protection, Edmonton, Alta. Pub. no. T/358. 22pp.

Willoughby, M.G. 1997b. Rangeland Reference Areas, Carbondale River, Range condition and trend from 1953-1995. Dept. of Environmental Protection, Edmonton, Alta. Pub. no. T/357. $25 \mathrm{pp}$.

Willoughby, M.G. and M.J. Alexander. 2000. A Range Condition Dilemma. Rangelands. 22(1) 23-26.

Willoughby, M.G., M.J. Alexander and B.W. Adams. 2003. Range plant community types and carrying capacity for the Montane subregion. $5^{\text {th }}$ approximation. Alberta Sustainable Resource Development. Public Lands Division. Edmonton, Alta. Pub. no. T/033. 223pp. 


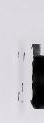

I

I

I

,

I

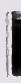

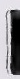

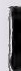

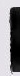

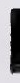

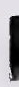

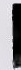

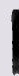


Appendix 1. Site characteristics of the rough fescue dominated reference areas in the Montane subregion.

Site characteristics

\begin{tabular}{|c|c|}
\hline Soil (subgroup) & $\begin{array}{l}\text { Orthic Black Chernozem }{ }^{6} \text {, Orthic Dk. Grey Chernozem } \\
\text { Rego Dk. Grey Chernozem }{ }^{2} \text {, Orthic Eutric Brunisol }\end{array}$ \\
\hline Parent material & Glacial Till $^{4}$, Glacial Fluvial ${ }^{5}$, Colluvial ${ }^{1}$ \\
\hline Surface Texture & Loam $^{5}$, Silty Loam ${ }^{4}$, Sandy Loam ${ }^{1}$ \\
\hline Effective texture & Clay Loam ${ }^{4}$, Loam ${ }^{4}$, Silty Loam ${ }^{1}$, Sandy Loam ${ }^{1}$ \\
\hline $\mathrm{pH}$ & $6-7.5$ \\
\hline Ah thickness $(\mathrm{cm})$ & $0-<10^{1}, 0-20^{6}, 0->20^{3}$ \\
\hline Humus form & Mull $^{10}$ \\
\hline Depth to Gleying & None $^{10}$ \\
\hline Moisture & Mesic $^{6}$, Submesic $^{4}$ \\
\hline Nutrient & Mesotrophic ${ }^{7}$, Permesotrophic ${ }^{3}$ \\
\hline Drainage & Well $^{10}$ \\
\hline Elevation (m) & $1469(1300-1660)$ \\
\hline Aspect & Variable \\
\hline Slope $(\%)$ & $7(1-25)$ \\
\hline Number of Soil Pits & 11 \\
\hline
\end{tabular}

${ }^{1}$ Indicates percentage of soil pits with this soil subgroup (ie 1=10\%) 
I

I

I

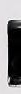

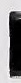

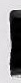

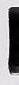

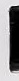

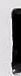

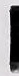

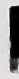

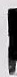

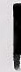

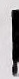



Bibliotheque et Archives Canada

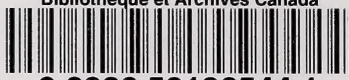

33286531265441 